This paper is published in the open archive of Mid Sweden University

DIVA http://miun.diva-portal.org

with permission of the publisher

Citation for the peer-reviewed published paper:

Friman L, Höglund H, Högberg H, Agnemo R. Tannin-Fe impregnated mechanical pulp : Part II: Bleachability and yellowing. Nordic Pulp and Paper Research Journal. 2004;19(4):525-531.

URL to article at publishers site:

http://dx.doi.org/10.3183/NPPRJ-2004-19-04-p525-531 


\title{
Tannin-iron impregnated thermomechanical pulp Part II: Bleachability and brightness reversion
}

\author{
Linda Friman, Hans Höglund and Hans-Erik Högberg, Mid Sweden University, Sundsvall, Roland Agnemo, Domsjö Fabriker, Örnsköldsvik, Sweden
}

\author{
KEYWORDS: Brightness reversion, Chelating agents, \\ Dithionites, Iron, Peroxides, Polyphenols, Tannins, \\ Thermomechanical pulps
}

SUMMARY: Tannins are polymeric, phenolic constituents found in the bark of pine and spruce. When reacting with iron ions, tannins form strongly coloured complexes. Thus, the presence of bark in the mechanical pulping process leads to decreased brightness of the pulp. In order to evaluate the effects of the presence of iron on the properties of pulp, we have impregnated thermomechanical pulp (TMP) with 30 parts per million (ppm i.e. $\mathrm{mg} / \mathrm{kg}$ ) iron either as $\mathrm{Fe}^{3+}$ or as tannin-iron complexes and studied how such treatments affect bleachability and heat-induced brightness reversion. The bleaching agents studied are hydrogen peroxide and sodium dithionite. Treatment of the tannin-iron impregnated pulp with $1 \%$ by weight of diethylenetriaminepentaacetic acid (DTPA) before bleaching with $4 \%$ hydrogen peroxide almost eliminated the brightness loss caused by the impregnation. Such a treatment also removed all of the added iron from both the tannin-iron and $\mathrm{FeCl}_{3}$ impregnated pulps. Approximately 5\% more of the added peroxide was required for oxidation of the tannins in the tanniniron impregnated pulp. Contrary to what was observed with peroxide bleaching, dithionite bleaching did not reduce the amount of iron in the pulps. Instead, the added iron and tanniniron negatively affected the dithionite bleaching, even if the pulps were extracted with DTPA before bleaching. It should therefore be advantageous to first bleach with peroxide, which removes most of the iron, and then with dithionite. Compared with dithionite, peroxide yields a more efficient bleaching. The reason for this is that the former reduces the light absorption coefficient, the k-value, more efficiently in the whole visible spectrum, whereas dithionite reduces it mainly at shorter wavelengths. In our experiments, the addition of tannin-iron or $\mathrm{FeCl}_{3}$ to the untreated pulp did not increase heat-induced brightness reversion. This is supported by the fact that although extraction of the samples with DTPA before bleaching lowered the iron content slightly, it did not affect the brightness reversion. The initial brightness reversion of the dithionite bleached pulps was larger than that observed for the peroxide bleached pulps.

ADDRESSES OF THE AUTHORS: Linda Friman (frimanlinda@hotmail.com), Hans Höglund (hans.hoglund@mh.se) and Hans-Erik Högberg (hans-erik.hogberg@mh.se): Department of Natural and Environmental Sciences, Mid Sweden University, SE-851 70 Sundsvall, Sweden.

Roland Agnemo (roland.agnemo@domsjoe.com): Domsjö

Fabriker, SE-891 80 Örnsköldsvik, Sweden.

Corresponding author: Hans-Erik Högberg

Compared with fully bleached chemical pulps, mechanical pulps have lower brightness and brightness stability. Thermally induced brightness reversion is accelerated by transition metals, especially iron (Gupta 1970). Metal complexes with some wood components, although normally present in only small amounts, have been reported to have strong light absorption in the visible spectrum, thus contributing to the colour of mechanical pulp (Polcin, Rapson 1972). Tannins are a group of wood components containing many phenolic groups, which can form coloured complexes with metal ions, such as $\mathrm{Fe}^{3+}$ (South, Miller 1998).

Norway Spruce (Picea abies) is the major raw material for mechanical pulp in Scandinavia. Condensed tannins are found in high concentrations in the bark of trees of the Pinaceae family e.g. spruce and pine. Spruce bark normally contains approximately $10 \%$ of tannins, but the content varies between $6 \%$ to $20 \%$ (Ullevålseter 1965). Compared with wood, bark contains 5-10 times higher concentration of iron (Young, Guinn 1966).

Pulpwood can become contaminated with tannins in two different ways, either through penetration into the wood from the surrounding inner bark on logs during storage both on land and in water (Ullevålseter 1965; Persson et al. 2002) or through inefficient bark removal prior to pulping.

The brightness of bleached mechanical pulps is in most cases improved by addition of a chelating agent before bleaching. This is due to the removal of harmful metals, which can otherwise form coloured complexes with some wood components and may also induce decomposition of bleaching agents (Polcin, Rapson 1972). Chelating agents, for example diethylenetriaminepentaacetic acid (DTPA), selectively bind those metal ions that are responsible for most of the brightness loss in peroxide bleaching, e.g. manganese. Traces of manganese decompose hydrogen peroxide (Rodriguez et al. 1996).

When dithionite bleaching is used, iron is the most harmful metal and it is also difficult to remove by chelating agents (Ganguli 1980).

Brightness stability of pulp is classified as either heat or light induced. Thermal yellowing is affected by moisture, $\mathrm{pH}$ and metal ions. Compared with unbleached pulp, both peroxide and dithionite bleached pulps show increased brightness reversion (Forsskåhl 2000).

We have previously studied tannin-iron complexes in solution and the effect of adding these or $\mathrm{Fe}^{3+}$ to thermomechanical pulp. Even though it was not possible to remove all of the added tannin-iron complexes or the iron from the treated pulps using extraction with e.g. DTPA or acid, the remaining iron did not cause increased brightness loss upon heating (Friman et al. 2004). Here we present our results from a study of how impregnation of pulp with $\mathrm{Fe}^{3+}$ ions and tannin-iron complexes influences the bleaching efficiency of peroxide and dithionite. The subsequent brightness reversion of the bleached pulps has also been studied. 


\section{Experimental}

For a description of materials, impregnations, metal analyses and brightness measurements see part $\mathrm{I}$ in this series. The extractions were made as described earlier in (method 1 in part I; Friman et al. 2004).

\section{Solutions}

Preparation of the solutions used for impregnations and the extractions were described in part I (Friman et al. 2004).

To $50 \mathrm{ml}$ tannin-iron solution $\left(\mathrm{FeCl}_{3}: 84.2 \mu \mathrm{mol} / \mathrm{l}\right.$; tannin: $168.4 \mu \mathrm{mol} / \mathrm{l})$ suitable amounts of $5 \%$ hydrogen peroxide $\left(\mathrm{H}_{2} \mathrm{O}_{2}\right)$ was added to obtain solutions of 0.00 , $0.07,0.14$ and $0.29 \% \mathrm{w} / \mathrm{w} \mathrm{H}_{2} \mathrm{O}_{2}$. The solutions were adjusted to $\mathrm{pH} 5$ and diluted to $100 \mathrm{ml}$. After 24 hours the ultraviolet-visible (UV-Vis) spectra and the residual peroxide were measured by a Varian Cary 100 Bio UVVis spectrophotometer and iodometric titration, respectively. The $5 \% \mathrm{H}_{2} \mathrm{O}_{2}$ was prepared by dilution of $>30 \%$ $\mathrm{H}_{2} \mathrm{O}_{2}$ (Merck) with deionised water and the concentration was determined by iodometric titration.

To $50 \mathrm{ml}$ of a tannin-iron, $\left(\mathrm{FeCl}_{3}: 84.2 \mu \mathrm{mol} / 1\right.$; tannin: $168.4 \mu \mathrm{mol} / \mathrm{l})$, of an iron $\left(\mathrm{FeCl}_{3}: 84.2 \mu \mathrm{mol}\right)$ and of a water (reference) solution, a suitable amount of $20 \%$ sodium silicate $\left(\mathrm{Na}_{2} \mathrm{SiO}_{3}\right), 12 \%$ sodium hydroxide $(\mathrm{NaOH})$, and $18 \% \mathrm{H}_{2} \mathrm{O}_{2}$ was added and diluted to $100 \mathrm{ml}$ to achieve the same concentrations as those that were used during peroxide bleaching, described below. Hence, the concentration of peroxide in solution was $0.40 \% \mathrm{w} / \mathrm{w}$. The $\mathrm{pH}$ of the solutions was $\mathrm{pH} 12$. The solutions were then heated in a water bath at $70^{\circ} \mathrm{C}$ for 3 hours. The UVVis spectra and the peroxide concentrations of the solutions were measured before and after heating.

\section{Bleaching}

\section{Peroxide bleaching:}

The bleaching conditions were $\mathrm{H}_{2} \mathrm{O}_{2} 4 \%, \mathrm{Na}_{2} \mathrm{SiO}_{3} 4 \%$, and $\mathrm{NaOH} 2.8 \%$, all w/w [relatively to oven dried (o.d.) pulp], at $70^{\circ} \mathrm{C}$ for 3 hours at $10 \%$ pulp consistency.

The pulp (6 g o.d.) was placed into a plastic bag and the required amount of $20 \% \mathrm{Na}_{2} \mathrm{SiO}_{3}, 12 \% \mathrm{NaOH}$, and $18 \% \mathrm{H}_{2} \mathrm{O}_{2}$ was added and diluted to achieve the bleaching conditions stated above. After mixing by hand, the plastic bag was placed in a water bath at $70^{\circ} \mathrm{C}$. After 3 hours the pulp was dewatered to pulp consistency of $15 \%$ and then diluted to $1.5 \%$ and mixed for one minute. The residual peroxide was determined by iodometric titration. The final $\mathrm{pH}$ after peroxide bleaching was determined to between $\mathrm{pH} 9.3$ and $\mathrm{pH}$ 10. Three separate bleaching experiments were made for each sample.

Dithionite bleaching:

The bleaching conditions were dithionite $1 \%$ at $80^{\circ} \mathrm{C}$ for one hour and at 3\% pulp consistency.

The bleaching solution was made by dissolving sodium dithionite powder $(0.8 \mathrm{~g} / \mathrm{l}$, Merck, containing $87 \% \mathrm{Na}_{2} \mathrm{~S}_{2} \mathrm{O}_{4}$ ) in deionised water and the $\mathrm{pH}$ was adjusted to approximately $\mathrm{pH} 11$ with $1 \mathrm{M} \mathrm{NaOH}$.

The pulp ( $4 \mathrm{~g}$ o.d.) was heated in a water bath thermostated to $80^{\circ} \mathrm{C}$ and mixed with $50 \mathrm{ml}$ bleaching solution and stirred during the reaction. After one hour the pulp was dewatered to pulp consistency of approximately $35 \%$ and then diluted to $1.5 \%$ and mixed for one minute. The final $\mathrm{pH}$ was determined to $\mathrm{pH} 4.7-\mathrm{pH}$ 6.4. The bleaching was done under a nitrogen atmosphere and all solutions and the pulp suspension were saturated with nitrogen for at least 10 minutes to avoid dissolved oxygen. Three separate bleaching experiments were made for each sample.

After bleaching, sheets with the basis weight of 40 $\mathrm{g} / \mathrm{m}^{2}$ for brightness measurements and metal analysis were produced after the $\mathrm{pH}$ of the pulp was adjusted to approximately $\mathrm{pH} 6$.

\section{Brightness reversion}

The samples were accelerated-aged at $150^{\circ} \mathrm{C}$ for $2.5,5$, 10,30 and 180 minutes in an oven.

\section{Results and Discussion}

\section{Abbreviations:}

Pulps:

R-pulp: Reference pulp, no impregnation.

TFe-pulp: Pulp containing $\sim 30$ parts per million iron [ppm (i.e. $\mathrm{mg} / \mathrm{kg}$ o.d. pulp)] after impregnation with a tannin-iron solution.

Fe-pulp: Pulp containing 30 ppm iron after impregnation with a $\mathrm{FeCl}_{3}$ solution.

Extractions and bleachings:

$\mathbf{U}$ : No extraction.

W: Extraction with water.

DTPA: Extraction with a DTPA solution.

Di: Bleaching with a sodium dithionite solution.

P: Bleaching with a hydrogen peroxide solution.

\section{Hydrogen peroxide reactions with tannin-iron- and $\mathrm{FeCl}_{3}$ - solutions}

First we examined how an aqueous solution of the tanniniron complexes reacted with varying amounts of added hydrogen peroxide. Thus, when a hydrogen peroxide solution $(0.14$ or $0.29 \% \mathrm{w} / \mathrm{w})$ was added to a tannin-iron solution, the characteristic peak of the latter at $565 \mathrm{~nm}$ (Friman et al. 2004) disappeared indicating that the complexes were destroyed and that the tannins were decomposed to give less coloured products (Fig. 1a).

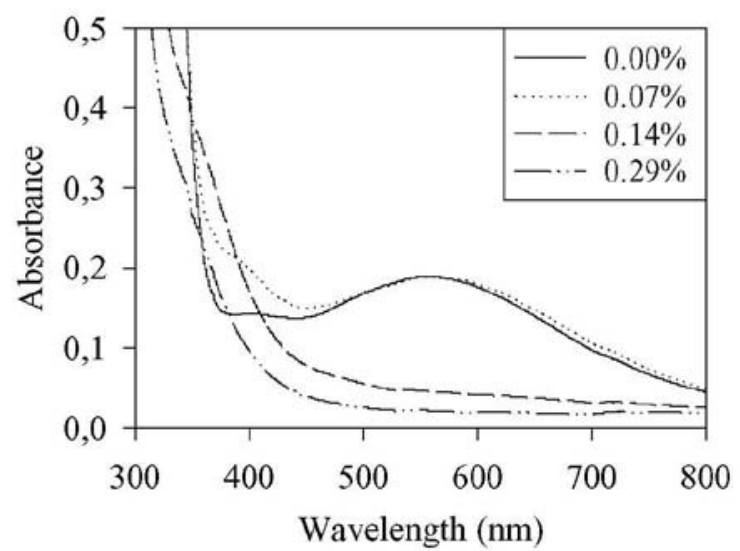

Fig 1a. UV-Vis absorbance spectra of solutions of the tannin-iron complexes (84 $\mu \mathrm{M}$ tannin, $42 \mu \mathrm{M}$ iron, $\mathrm{pH}$ 5) after reaction with various amounts of $\mathrm{H}_{2} \mathrm{O}_{2}$ in aqueous solution for 24 hours. 


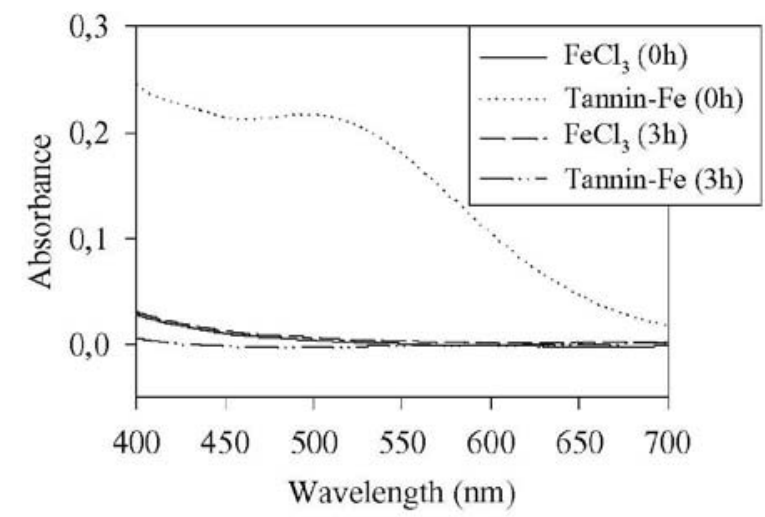

Fig 1b. UV-Vis absorbance spectra of solutions of the tannin-iron complexes and $\mathrm{FeCl}_{3}(72 \mu \mathrm{M}$ tannin, $36 \mu \mathrm{M}$ iron, $\mathrm{pH} 12)$ before and after reaction with 0.4 weigth- $\% \mathrm{H}_{2} \mathrm{O}_{2}$ in aqueous solutions for 3 hours at $70^{\circ} \mathrm{C}$.

This treatment also led to a decrease of $\mathrm{pH}$ from $\mathrm{pH} 5$ to $\mathrm{pH} 3.3$ indicating that some phenolic groups of tannin were oxidised to acidic groups resulting in less coloured complexes between iron and the products. After peroxide treatment of the tannin-iron solution for 24 hours the solutions with 0.14 or $0.29 \% \mathrm{w} / \mathrm{w}$ peroxide were almost colourless, but not the solution with $0.07 \% \mathrm{w} / \mathrm{w}$ peroxide. However, most of the added peroxide remained in all the solutions and after a longer reaction time even the solution with $0.07 \% \mathrm{w} / \mathrm{w}$ peroxide was decolourised.

The decomposition of hydrogen peroxide is catalysed by iron via the so called Fenton driven Haber-Weiss mechanism, but it may also be base-catalysed (Colodette et al. 1988; Isbell et al. 1975). In order to determine if these mechanisms had any influence on the decomposition of the tannin-iron complexes, we performed the same experiment as described in the paragraph above, but instead of performing it at $\mathrm{pH} \mathrm{5,} \mathrm{pH} 12$ was used. After reaction with $0.4 \% \quad \mathrm{w} / \mathrm{w}$ peroxide under alkaline conditions, the tannin-iron solution became less coloured than the $\mathrm{FeCl}_{3}$-solution, which remained unchanged i.e. slightly yellow (Fig 1 b). This indicated, that the decomposition products of peroxide, regardless of mechanism, could oxidise tannin, probably to yield degradation products containing carboxylate ions, which might give colourless complexes with iron. As described in part I of this series, when the $\mathrm{pH}$ is increased, the colour of the tannin-iron complexes becomes stronger (Friman et al. 2004). Thus, the observed decomposition of the tanniniron complexes to colourless ones at higher $\mathrm{pH}$ was due to peroxide reactions and not to the increase of $\mathrm{pH}$.

\section{Removal of iron from impregnated pulp}

The next step was to investigate if hydrogen peroxide had the same effect on iron added to the pulp. In experiments with impregnated pulps, a reference pulp $(\mathbf{R})$ was used as the control pulp. It contained between 1-5 ppm iron.

We have already found that extractions with water $(\mathbf{W})$ and DTPA remove approximately $10 \mathrm{ppm}$ and $15 \mathrm{ppm}$ iron, respectively, of the $\sim 30 \mathrm{ppm}$ iron originally present in both the tannin-iron ( $\mathbf{T F e}$ ) and $\mathrm{Fe}^{3+}(\mathbf{F e})$ impregnated pulps. However, complete removal of all the added iron or tannin-iron complexes from the impregnated Fe- and TFe-pulps is not possible, not even by using acid

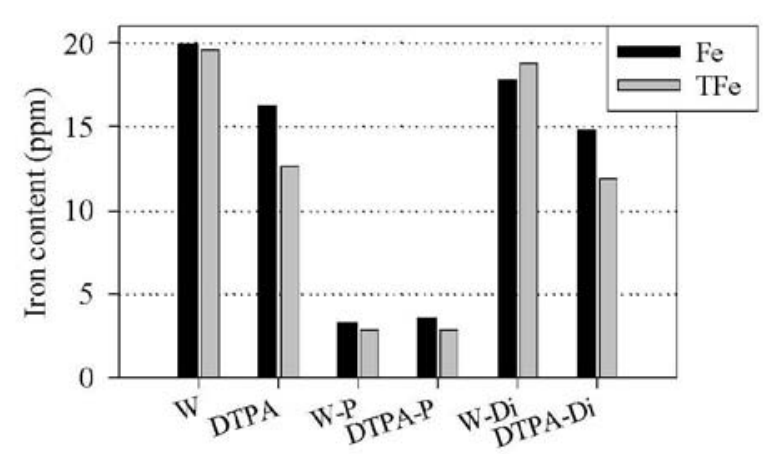

Fig 2. Iron-levels (ppm) in pulp impregnated with either $\mathrm{FeCl}_{3}$ or tannin-iron complexes after various bleaching and/or extractive treatments. For abbrevaiations see text. The mean value and the standard deviation are calculated from three replicates.

extraction at $\mathrm{pH} 2$, which removes approximately $20 \mathrm{ppm}$ of the added iron (Friman et al. 2004).

We now found that bleaching with peroxide completely removed both the added iron and the tannin-iron, leaving pulps with the same iron-levels as the R-pulp (Fig 2). A possible explanation for this might be that the iron was initially bound to insoluble polymers, which on peroxide oxidation were decomposed to smaller fragments, which formed water soluble iron-complexes that were extracted by water (cf. the behaviour in solution, discussed above). A result contradicting ours has been presented by Rodriguez et al. (1996), who have shown that iron (and also copper) cannot be removed from the pulp during peroxide bleaching. However, after impregnation with $\mathrm{FeCl}_{2}$ or $\mathrm{FeCl}_{3}$ and before DTPA extraction, about ten times more iron was present in their pulps than in ours.

Bleaching with dithionite did not significantly decrease the iron-levels of the TFe- and Fe-pulps (Fig 2).

\section{Bleaching}

Hydrogen peroxide

Lorås (1976) has shown that thermomechanical pulp (TMP) containing $1-3 \%$ by weight of bark can be bleached to a considerable degree with peroxide, but when bark is present, the final brightness is lower. Persson et al. (2002) have observed decreased brightness of pulps from spruce logs damaged by tannins and this damage is difficult to regain by peroxide bleaching. The explanation given for this is that the bark tannins diffuse inside the cell wall structure, which makes them less exposed to bleaching agents.

Contrary to the results described in the previous paragraph, we found that peroxide bleaching of the TFepulp led to the disappearance of the characteristic peak at $565 \mathrm{~nm}$ for the tannin-iron complexes so these must have been transformed into less coloured products (see discussion above). The resulting delta light absorption coefficients $\left[\Delta(\mathrm{k})\right.$-values $\left.=\mathrm{k}_{\mathrm{TFe}}-\mathrm{k}_{\mathrm{R}}\right]$ were however not equal to zero indicating that some chromophores originating from the tannin-iron impregnation still remained in the pulp (Fig 3). For the TFe-pulp extracted with DTPA and then bleached with peroxide, the $\Delta \mathrm{k}$-values were slightly lower than those observed for pulp extracted with only water prior to peroxide bleaching. One possible explanation for this is that the pulp, which was not pre-extracted with 


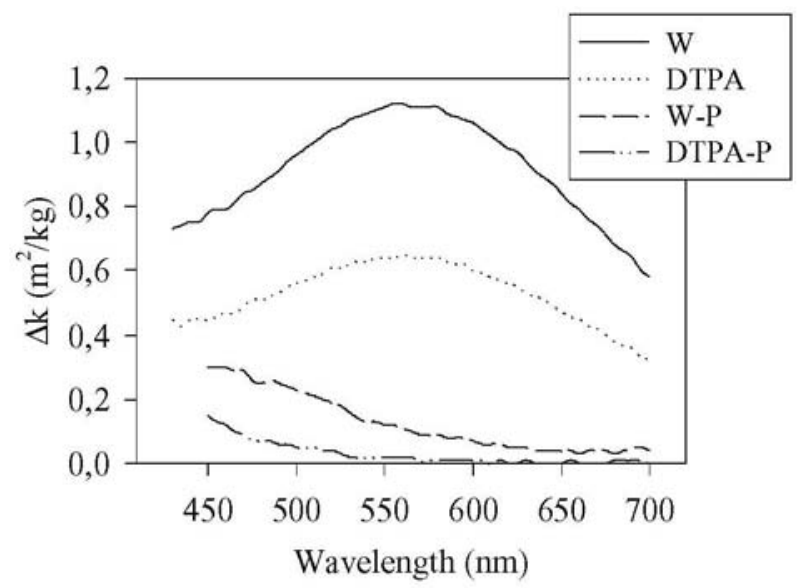

Fig 3. The $\Delta \mathrm{k}$-values of sheets derived from tannin-iron impregnated pulp after various extractive treatments and, in some cases, followed by peroxide bleaching. $\Delta \mathrm{k}=\mathrm{k}$ (impregnated) $-\mathrm{k}$ (reference) . For abbreviations see text.

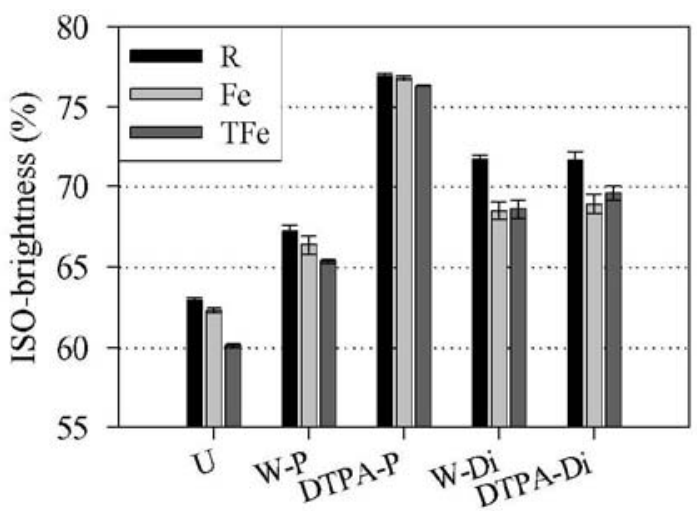

Fig 4. ISO-brightness (\%) of sheets made from pulp before and after various bleaching and extractive treatments. For abbreviations see text. The mean value and the standard deviation are calculated from three measurements on each sheet from at least three replicates on each treated pulp.

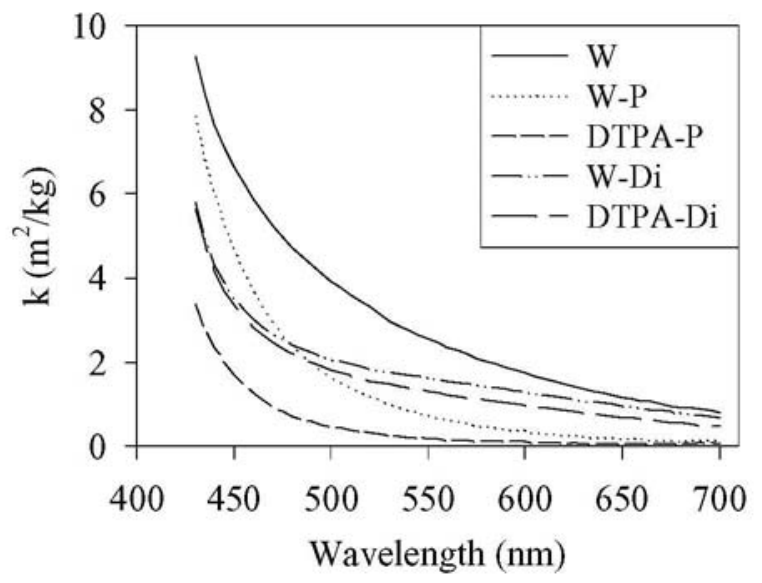

Fig 5. The k-spectra of sheets derived from tannin-iron impregnated pulp after various bleaching and extractive treatments. For abbreviations see text.

DTPA, had a higher manganese-level leading to less efficient bleaching (see discussion below). Another explanation may be that the DTPA pre-extracted TFepulp contains a lower level of coloured tannin-iron complexes and hence is easier to bleach than the water pre-extracted TFe-pulp (Fig 2 and Fig 3).

Gupta (1970) has shown that, for peroxide bleaching, iron does not have a negative effect on bleachability. In addition, part of the brightness reduction due to iron is regained during bleaching. In agreement with this, we found that the peroxide bleached TFe- and Fe-pulps gave almost the same ISO-brightness as the peroxide bleached reference pulps. This indicated that when we used peroxide, the presence of added iron and tannin-iron did not influence the bleachability (Fig 4). Contrary to the results of Gupta (1970), we found that the addition of iron did not have any significant influence on the brightness of the pulp.

In order to get a maximal increase in pulp brightness after peroxide bleaching, the manganese concentration in a pulp should not be higher than 4 ppm (Rodriguez et al. 1996). The water extracted pulps contained approximately $30 \mathrm{ppm}$ manganese. This high content leads to unwanted manganese-catalysed decomposition of peroxide. Hence, compared with water extracted pulp bleached with peroxide, we found that extraction with DTPA prior to the peroxide bleaching gave a much brighter pulp, which could be attributed to the low manganese content, $0.3 \mathrm{ppm}$, in the DTPA-extracted pulp (Fig 4 and Fig 5).

Provided that DTPA-extraction preceded bleaching, peroxide increased the ISO-brightness by $15-17 \%$. Otherwise the increase was approximately 10 ISO- $\%$ lower. The largest increase in ISO-brightness was observed for the TFe-pulp, because the tannin-iron complexes were destroyed (Fig 4).

For the pulps which were not extracted with DTPA prior to bleaching, the amount of residual peroxide was $\sim 0.2-0.9 \%$ of the original amount added. For those extracted with DTPA prior to bleaching the amount of residual peroxide was much higher ( $24-34 \%$ ) probably because of the lower manganese-content (see discussion above). For pulps extracted with DTPA prior to bleaching, there was no significant difference in residual peroxide for the iron impregnated pulp and the reference pulp. This indicated that the iron content in the pulp did not significantly enhance peroxide decomposition. Rodriguez et al. (1996) have also shown that the metals not desorbed from the pulp e.g. iron and copper does not have any significant effect on peroxide decomposition. For the DTPA pre-extracted pulps, the residual peroxide after bleaching of the reference pulp was somewhat higher than that of the TFe-pulp. This is probably due to consumption of peroxide when the phenolic groups in the tannin are oxidised (Fig 6).

\section{Sodium dithionite}

Addition of iron to TMP decreases the bleachability by dithionite (Hart 1981). By extraction with a chelating agent prior to bleaching, this decrease may however be recovered, even though not all of the added iron could be removed as approximately $50 \mathrm{ppm}$ iron remains in the investigated pulp (Ganguli 1980). The detrimental effect iron has on dithionite bleaching may be because it decomposes dithionite. Alternatively, reductive bleaching forms more phenolic groups, which may form coloured complexes with iron ions.

In accordance with result by Ganguli (1980), we observed that dithionite bleaching after pre-extraction 


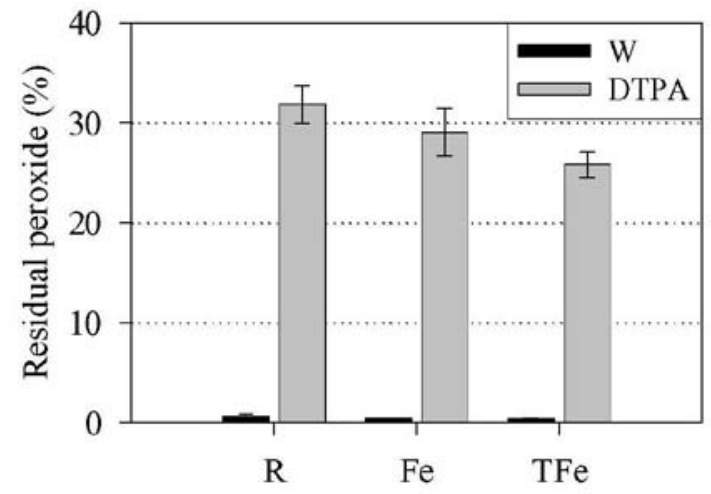

Fig 6. Residual peroxide (\%) in the filtrate of solutions used for bleaching pulp pre-extracted with either water (W) or DTPA. The mean value and the standard deviation are calculated from three replicates.

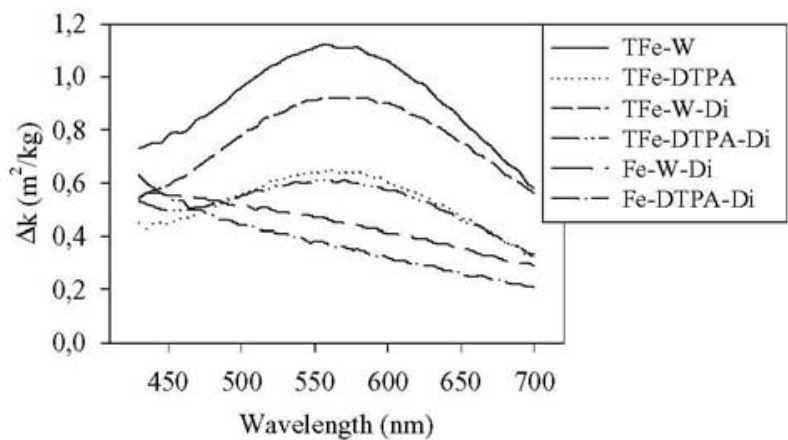

Fig 7. The $\Delta \mathrm{k}$-values of sheets derived from either $\mathrm{FeCl}_{3}$ or tanniniron impregnated pulp after various extractive treatments and, in some cases, followed by dithionite bleaching. $\Delta \mathrm{k}=\mathrm{k}$ (impregnated) $-k$ (reference). For abbreviations see text.

with DTPA gave a small increase in brightness, probably due to removal of some iron (Fig 5). However, contrary to Ganguli (1980) the remaining amount of iron in the Fe-pulp $(\sim 15 \mathrm{ppm})$ affected the dithionite bleaching negatively (Fig 4 and Fig 7).

We also found that dithionite bleaching did not lead to destruction of the tannin-iron complexes when the pulp was pre-extracted with DTPA. This was evident, because after bleaching the characteristic peak at $565 \mathrm{~nm}$ for tannin-iron remained unchanged. Dithionite bleaching destroyed however some tannin-iron complexes when the TFe-pulp had been pre-extracted with water instead of DTPA (Fig 7).

After dithionite bleaching the ISO-brightness was increased by $7-11$ ISO- $\%$. The smallest increase was observed for the Fe-pulp, which could be due to a high level of available iron ions leading to decomposition of the dithionite (Fig 4).

Peroxide vs. dithionite

As mentioned above bark contains a large amount of tannins and has high iron content and according to Lorås (1976), bark is easier to bleach with peroxide than with dithionite. Thus our results, in which peroxide but not dithionite bleaching destroyed the coloured tannin-iron complexes offer an explanation for the observation of Lorås (1976) (Fig 3 and Fig 7).

After dithionite bleaching the k-values were reduced and this was most pronounced at shorter wavelengths, whereas after peroxide bleaching the $\mathrm{k}$-values are more reduced over the visible wavelengths. Peroxide and

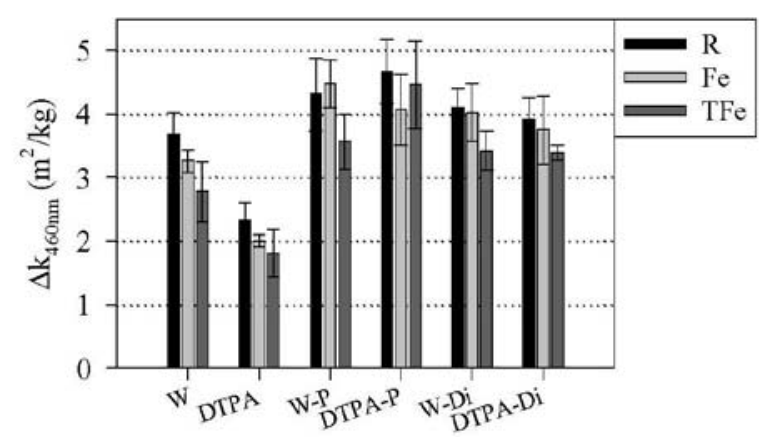

Fig 8. The $\Delta \mathrm{k}$-values at $460 \mathrm{~nm}$ for samples of aged sheets $\left(150^{\circ} \mathrm{C}\right.$, $180 \mathrm{~min}$ ) made from various pulps, which had been exposed to various pre-extractions and, in some cases followed by bleaching. $\Delta \mathrm{k}=\mathrm{k}(\mathrm{aged})-\mathrm{k}$ (not aged). For abbreviations see text. The mean value and the standard deviation are calculated from three measurements on each sheet from three replicates on each treated pulp.

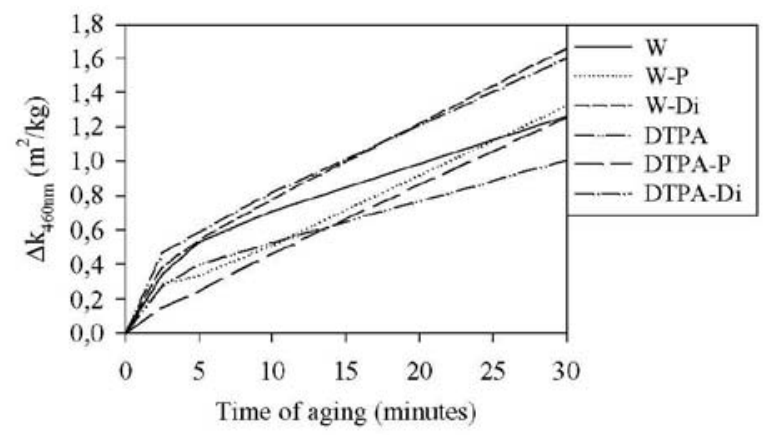

Fig 9. The $\Delta \mathrm{k}$-values at $460 \mathrm{~nm}$ for aged sheets $\left(150^{\circ} \mathrm{C}\right)$ after various time periods. Sheets were made from reference pulp. $\Delta \mathrm{k}=$ k(aged) - k(not aged). For abbreviations see text.

dithionite decompose in the presence of manganese and iron, respectively (see discussion above) so extraction of the pulps with DTPA prior to peroxide and dithionite bleaching yields lower $\mathrm{k}$-values in the whole visible spectrum due to more efficient bleaching. This is more pronounced for peroxide than dithionite bleaching because the manganese is much easier to remove by DTPA than iron and manganese does not effect dithionite bleaching (Fig 5).

\section{Brightness reversion}

In order to evaluate how peroxide and dithionite bleaching of the tannin-iron and iron impregnated pulp samples influenced heat-induced brightness reversion sheets prepared from these pulps were artificially aged at $150^{\circ} \mathrm{C}$ for $2.5,5,10,30$ and 180 minutes.

According to Gupta (1970), both $\mathrm{Fe}^{2+}$ and $\mathrm{Fe}^{3+}$ have a detrimental effect on the heat-induced brightness reversion of both peroxide and dithionite bleached groundwood pulp. Contrary to their results we observed no significant difference in brightness reversion for the bleached reference. The Fe- or TFe-pulps indicate that iron had no significant influence on heat-induced brightness reversion (Fig 8).

It is known that after bleaching pulp new structural elements are formed which are sensitive to oxidation yielding new chromophores (McLellan et al. 1990). Hence, our bleached samples did yellow more than the unbleached ones (Fig 8 and Fig 9).

Lee et al. (1989) found that the brightness reversion is 


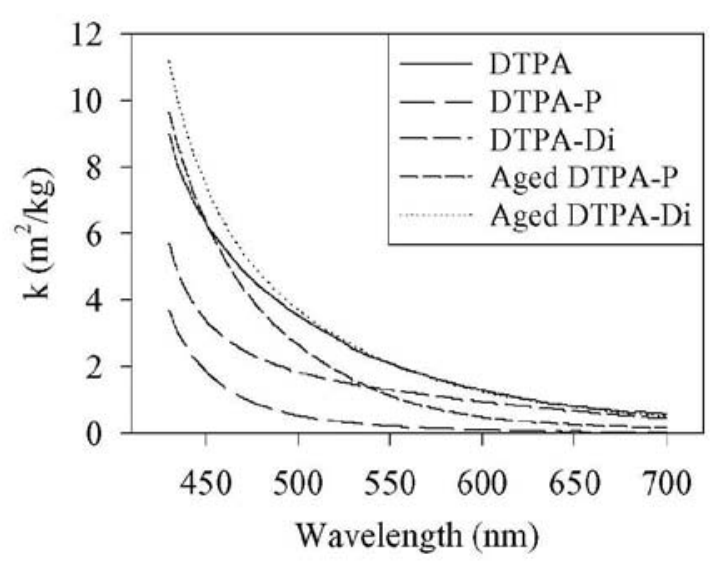

Fig 10. The k-spectra for non-aged and aged (Aged: $150^{\circ} \mathrm{C}, 180$ min) sheets made from tannin-iron impregnated pulps, which had been exposed to various pre-extractions and, in some cases followed by bleaching. For abbreviations see text.

higher for dithionite than for peroxide bleached pulp. The higher aging observed for dithionite-bleached pulp may be attributed to the presence of higher amounts of hydroquinoid moieties, leucochromophores, which are formed when dithionite reduces quinoid moieties in the pulp (Lee et al. 1989; Polcin, Rapson 1971). During heat aging, the colourless hydroquinones are oxidised in air to coloured quinones (cf. Gellerstedt, Pettersson 1980). Consistent with these observations, we found that the initial brightness reversion of our dithionite bleached samples was higher than that of the peroxide bleached samples (Fig 9).

Lee et al. (1989) have shown that DTPA-extraction inhibits heat-induced brightness reversion of both unbleached and peroxide bleached mechanical pulps, but not of dithionite bleached ones. In the latter case heat induced oxidation of large amounts of leucochromophores is enough to overwhelm the effects of the removal of metal ions. This is in accordance with our results, which show no significant difference in heat-induced brightness reversion of dithionite bleached pulps whether or not they have been pre-extracted with DTPA, and in the case of unbleached pulp, our previous work supported their conclusions (see part I, Friman et al. 2004). However, in contrast to the results by Lee et al. (1989) ours show that DTPA extraction before peroxide bleaching does not inhibit the heat-induced brightness reversion (Fig 8 and Fig 9).

For heat-induced aging of bleached pulps, we found that the $\mathrm{k}$-values showed the highest increase at the shortest wavelengths in the visible region of the spectrum. When dithionite bleached samples were exposed to heat for long times, the $\mathrm{k}$-values became higher than those of the unbleached pulp. The peroxide bleached pulp yellowed to a similar extent as the dithionite bleached pulp did. However, after aging the low k-values observed after the peroxide bleaching, still remained for longer wavelengths (Fig 10).

\section{Recommendations to the mechanical pulp industry}

This work has shown that it is difficult to completely eliminate the iron present in the pulp by treatment with a chelating agent. However, under peroxide bleaching conditions, most of the iron initially present in the pulp is removed after a subsequent water extraction stage.

This is beneficial for the final pulp brightness, because iron cause a brightness loss especially when it is complexed to wood components and the presence of iron also limits the response in terms of brightening, when dithionite is used as a bleaching agent.

Therefore, in order to avoid the harmful influence of residual iron, a two stage bleaching procedure can be recommended for mechanical pulp, first a hydrogen peroxide stage, which after efficient washing is followed by a second dithionite bleaching stage.

\section{Conclusions}

For thermomechanical pulp impregnated with $\mathrm{Fe}^{3+}$ alone or with tannin-iron complexes, the bleachability of peroxide and dithionite and the subsequent heat-induced brightness reversion were investigated. The main findings are:

- Addition of hydrogen peroxide to a tannin-iron solution destroys the coloured complexes.

- Bleaching with $4 \%$ peroxide regained almost all of the brightness loss caused by the addition of tannin-iron complexes to the thermomechanical pulp. This is especially evident when the pulp is extracted with DTPA prior to bleaching.

- When peroxide is used as the bleaching agent, the presence of tannin-iron complexes or iron in the pulp does not affect the bleachability.

- Whereas addition of iron to the pulp does not affect peroxide decomposition, added tannin-iron leads to a slightly higher consumption of peroxide probably due to oxidation of tannin.

- After the peroxide bleaching almost all of the added iron is removed from both the iron and the tanniniron impregnated pulps. This can be due to oxidation and decomposition of iron-complexing polymers into smaller soluble fragments in which the iron ions may still be bound in a colourless complex. These are then easily washed out with water.

- As iron added to thermomechanical pulp is removed by hydrogen peroxide bleaching, adding peroxide prior to refining may be a method to reduce the brightness loss originating from bark in the thermomechanical pulping process.

- Bleaching with dithionite is much less efficient than that using peroxide. This is partly due to the fact that dithionite is decomposed by iron. Therefore bleaching of pulps first with peroxide, in order to reduce the iron content, and then with dithionite is recommended.

- The added iron amount, as $\mathrm{Fe}^{3+}$ or as tannin-iron complexes, does not influence the heat-induced brightness reversion.

\section{Acknowledgement}

The authors wish to thank the Bo Rydin foundation for financial support. We are also grateful to SCA Graphic Research for allowing us use their inductively coupled plasma (ICP) and other equipment. We thank Dr. John Kettle for valuable comments. 


\section{Literature}

Colodette, J.L., Rothenberg, S. and Dence, C.W. (1988): Factors affecting hydrogen peroxide stability in the brightening of mechanical and chemimechanical pulps. Part I: Hydrogen peroxide stability in the absence of stabilizing systems, J. Pulp Paper Sci., 14:6, J126-J132.

Forsskåhl, I. (2000) in Forest products chemistry, Finnish paper engineers' association and Tappi Press, Helsinki, Stenius, P. (Ed.), 277-332.

Friman, L. Höglund, H., Agnemo, R. and Högberg, H.-E.: Tannin-iron impregnated thermomechanical pulp. Part I: Effects of extractions and heat on brightness, Nordic Pulp Paper Res. J., 19:2, 229-236.

Ganguli, K.K. (1980): Sodium hydrosulfite bleaching of TMP improved with metal chelants, Pulp Paper, 54:10, 108-112.

Gellerstedt, G. and Pettersson, B. (1980): Autooxidation of lignin, Svensk Papperstidn., 83:11, 314-318.

Gupta, V.N. (1970): Effect of metal ions on brightness, bleachability and colour reversion of groundwood, Pulp Paper Mag. Can., 71:18, 69-77.

Hart, J.R. (1981): Chelating agents in the pulp and paper industry, Tappi, 64:3, 43-44.

Isbell, H.S., Parks, E.W. and Naves, R.G. (1975): Degradation of reducing sugars and related compounds by alkaline hydrogen peroxide in the presence and absence of iron and magnesium salts, Carbohyd. Res., 45, 197-204.

Lee, J., Balatinecz, J.J. and Whiting, P. (1989): The optical properties of eight eastern canadian wood species. IV. Brightness stability, Int. Symp. Wood Pulp. Chem. Proc., Raleigh, NC, TAPPI Press, Atlanta, 529-534.
Lorås, V. (1976): Brightening of thermomechanical pulp, Tappi, 59:11; 99-101. McLellan, F., Colodette, J.L., Fairbank, M.G. and Whiting, P. (1990): Factors affecting ambient thermal reversion of high-yield pulps, J. Pulp Paper Sci., 16:6, J173-J179,

Persson, E., Bergquist, J., Elowson, T., Jäkärä, J. and Lönnberg, B. (2002): Brightness, bleachability and colour reversion of groundwood made of wet- and dry-stored Norway spruce (Picea abies) pulpwood, Pap. Puu, 84:6, 411-415.

Polcin, J. and Rapson, W.H. (1971): Effects of bleaching agents on the absorption spectra of lignin in groundwood pulps: Part II. Oxidative-Reductive bleaching, Pulp Paper Mag. Can., 72:3, 80-91.

Polcin, J. and Rapson, W.H. (1972): Sapwood and heartwood groundwood of western hemlock and jack pine. Part III. Influence of solvent extraction on the bleaching of pulps, Pulp Paper Mag. Can., 73:1, 86-92.

Rodriguez, S.K., Wilson, K.L. and Francis, R.C. (1996): Effect of adsorbed transition metals on hydrogen peroxide bleaching of thermomechanical pulp, 82nd Annual Meeting, Technical Section, Can. Pulp Paper Ass. (CPPA), B237-B246.

South, P.K. and Miller, D.D. (1998): Iron binding by tannic acid: effects of selected ligands, Food Chemistry, 63:2, 167-172.

Ullevålseter, R.0. (1965): Tanninskade på ubarket grantommer - Storage of unbarked spruce cause damage of tannin in pulp, Norsk skogsindustri, 11, 475-485.

Young, H.E. and Guinn, V.P. (1966): Chemical elements in complete mature trees of seven species in Maine, Tappi, 49:5, 190-197.

Manuscript received August 17, 2004 Accepted September, 2004

\section{Continues from page 524}

\section{Effect of using pH-reducing agents in brown stock...}

\begin{abstract}
Acknowledgements
Financial support from the research foundation, Stiftelsen Nils och Dorthi Troëdssons Forskningsfond is gratefully acknowledged. Södra Cell AB in Värö, Sweden, is acknowledged for their assistance in supplying pulp. The authors wish to thank Mr. Athi Vanninen for skillful technical construction and maintenance of technical equipment and Mr. Lars Göran Johansson for his adroit technical assistance.
\end{abstract}

\section{Literature}

Andersson, R., Lidén, J., Öhman, L-0. (2003): "The Donnan theory applied to pulp washing-Experimental studies on the removal of anionic substances from an assumed fiber lumen volume and from the fiber wall", Nordic Pulp Paper Res. J. 18(4), 404.

Ala-Kaila, K., Alén, R. (1999). "Dynamic response on pH and the transient behavior of some chemical elements in pulp-water suspensions" Nordic Pulp Paper Res. J. 16(2), 149.

Bokström, M., Rasimus, R. (1995): "Method of washing of alkaline pulp by adding carbon dioxide to the pulp" Patent Number US5429717.

Bokström, M., Kontola, P. (1995). "Improvement of pulp washing by addition of carbon dioxide" TAPPI Pulping Conference Proceedings, TAPPI Press, Atlanta, vol. 2, p. 669.

Chisholm, E. (1998): "Improving brown stock washing efficiency using $\mathrm{CO}_{2}$ to acidify post oxygen wash press filtrate". Irving Pulp \& Paper Ltd., 84th Annual meeting, Technical Section CPPA. p. B319.

Dence, C.W. (1992). The determination of lignin. In Methods in lignin chemistry; Lin, S.Y., Dence, C.W. Eds.; Springer-Verlag: Berlin, Germany, pp. 33-61.

Edwards, L., Rydin, S. (1975): "Washing of pulps. Part 3. Transfer rates of dissolved sodium and lignin from pulps in dilute, agitated suspension" Svensk Papperstidn. 78(16), 577.

Eriksson, G. (1991): "Inverkan av hög temperatur vid tvättning av kemisk massa"
Licentiate thesis, Department of Chemical Engineering Design, Chalmers University of Technology.

Girard, R., Ho, C., Guthrie, P., Campbell, P. (1999): "The effects of carbon dioxide on the efficiency of various brown stock washers" TAPPI Pulping Conference Proceedings, TAPPI Press, Atlanta, vol. 3, p. 1225.

Grén, U., Hedström B. (1967):"Fluid flow and pressure drops in thick beds of cellulose fibers" Svensk Papperstidn., 70(10), 339

Hartler, N. (1978): "Sorption cooking: Yield increase for unbleached alkaline pulps through sorption of organic substances from the black liquor" Svensk Papperstidn. 81(14), 457.

Li, J., Phoenix, A., MacLeod, J.M. (1996): "Diffusion of lignin macromolecules within the fibre walls of kraft pulp, Part 1 : Determination of the restricted diffusion coefficient under alkaline conditions" Pulp washing. Vancouver, British Columbia 7-10. October, p. 139

Luthe, C., Berry, R., Nadeau, L. (2003) "How does carbon dioxide improve brownstock washing?. TAPPI Technical Conference, Fall 2003.

Norberg, C., Lidén, J., Lindgren, J., Öhman, L-0 (2001). "Use of carbon dioxide in the production of sulfate pulp" SPCI International Conference on New Available Techniques Proceedings, SPCl, Stockholm, vol. 1, p. 36.

Pakarinen, H., Leino, H. (2001): "Benefits of using carbon dioxide in the production of DIP containing newprint" Wochenblatt fûr Papierfabrikation 14/15.

Sundberg, K, Lassus, A., Holmback, A., Hemming, J., Holmbom, B. (1997): "Determination of fatty and resin acid calcium soaps" 9th International symposium on wood and pulping chemistry (ISWPC), Montreal, Que, Canada, 9-12 June, p. 108-1

Sundin, J. (2000): "Precipitation of kraft lignin under alkaline conditions" Ph.D.thesis, Royal Insitute of Technology, Stockholm, Sweden.

Östberg, G., Ohrn, M., Kvist, E. (1995): "Use of carbon dioxide in the production of sulfate pulp" SPCl International Conference on New Available Techniques Proceedings, SPCl, Stockholm, vol. 1, p. 508.

Manuscript received June 6, 2004 Accepted September, 2004 